Images

VOL.VII / NO.13-14

Poznań 2009-2010

ISSN 1731-450X

\title{
Muzy w intymnym świetle. \\ O przemianach w sztuce Odwilzy i Października
}

Teren obserwacji: sztuka polska dekady lat 50. Nie któraś z jej oddzielnie rozpatrywanych gałęzi, lecz widok ogólny na koronę wspaniałego drzewa. Czas nagłego rozkwitu: pełna wyrazu, rozłożysta, wielodziedzinowa całość. Temat: przełom estetyczny, jaki się wtedy dokonał. Głęboka transformacja rozmaitych form twórczości zapisana w wierszach, powieściach, opowiadaniach, piosenkach, dziennikach, obrazach malarskich, rzeźbach, fotografiach, filmach i wszelkich innych dziedzinach twórczości.

Spójrzmy na ów estetyczny przełom z perspektywy szerszej niż horyzont jednej tylko dziedziny sztuki. Czy jest coś, co łączy wszystkie te indywidualne poszukiwania i odkrycia, coś, co pozwala nam odnaleźć zawarty w nich wspólny mianownik? Coś, dzięki czemu liryka, grafika, proza, malarstwo, rzeźba, muzyka, fotografia, teatr czy film tamtego czasu - nie tracąc swej artystycznej autonomii - okazują się do nas mówić jednym wspólnym głosem?

Sztuka Odwilży[ ${ }^{1}$ ] i Października nadal budzi żywe zainteresowanie; nic dziwnego, że doczekała się ona różnorakich opracowań. W studiach tych $\mathrm{z}$ reguły dochodzi jednak do głosu przede wszystkim polityka, a refleksja polityczna dominuje niemal zawsze nad refleksją estetyczną, upodrzędniając ją, lekceważąc i spychając na dalszy plan. Całkiem niesłusznie. Owszem, interpretacja polityczna pozwala niejedno zrozumieć i wyjaśnić. Ogranicza jednak pole widzenia interpretatora, zawężając je do pewnego kręgu spraw, w centrum których sytuuje się wyłącznie ideologia jako domena podporządkowująca sobie resztę.

Nie zamierzam tutaj całkowicie abstrahować od polityki. Pragnę tylko zauważyć, że w badaniach nad sztuką tamtego okresu, zbyt mało uwagi poświęcano dotąd przemianom zachodzącym wewnątrz niej samej. Przemianom w sferze wyboru i szczególnego zastosowania takich, a nie innych środków wyrazu i konwencji artystycznych, w rezultacie których daje o sobie znać prywatność, osobność i intymność, a wraz z nią negujące estetyczne wzorce socrealizmu - całkiem odmienne - sposoby przedstawiania ludzkiego życia.

[1] W roku 1996 Muzeum Narodowe w Poznaniu zaprezentowało znakomitą przekrojową wystawę zatytułowaną „Odwilż”, której pomysłodawcą i kuratorem był historyk sztuki, prof. Piotr Piotrowski z UAM. Zob. wydaną z tej okazji pracę zbiorową pt. Odwilż.
PRZEŁOM

ESTETYCZNY
Sztuka około 1956 roku, pod red. P. Piotrowskiego, Poznań 1996 oraz książkę Piotra Juszkiewicza (Od rozkoszy historiozofii do gry w nic. Polska krytyka artystyczna czasu Odwilzy, Poznań 2006). 
Jednym słowem: za dużo polityki (nawet, gdyby miała to być wyłącznie polityka kulturalna), a za mało estetyki. Szkoda, bo w moim przekonaniu właśnie skupienie na życiu jednostki i zafascynowanie sferą prywatną człowieka nadało polskiej sztuce lat Odwilży i Października ów niezwykle pociągający wyraz. I ono przesądziło ostatecznie o spójnym charakterze: malarstwa, filmu, grafiki, poezji, prozy, teatru, muzyki i innych dziedzin sztuki tamtego okresu. Probierzem tych przemian stało się rosnące - i z roku na rok coraz bardziej konsekwentne - zainteresowanie artystów życiem wewnętrznym jednostki. Właśnie ten aspekt własnej sztuki wielu z nich uznało za najważniejszy.

POLSKI

KAMMERSPIEL
Można tu mówić - bynajmniej nie na wyrost - o szczególnego rodzaju wspólnocie ponadjednostkowego instynktownego dążenia. O zbiorowym tropizmie twórców przejawiającym się w różnych domenach twórczości artystycznej. Dążenie owo, za sprawą którego z czasem odkryte zostało poprzez sztukę samo istnienie człowieka jako pewien jej arcynośny temat, przenika najambitniejszą i najbardziej wartościową rodzimą twórczość tamtej doby: od Różewicza, Herberta, Munka, Hasa i Lebensteina, po Białoszewskiego, Mrożka, Dygata, Szymborską czy Nowosielskiego.

Stalinizm w sztuce polskiej nie skończył się 5 marca 1953 roku i nie ustąpił ot, tak sobie, $\mathrm{z}$ dnia na dzień. Jeśli mówimy o przełomie, jakim było ostateczne odrzucenie go przez elitę naszych najwybitniejszych twórców, trzeba mieć na względzie nie nagłe zerwanie, lecz stopniowy i długotrwały, trwający kilka lat proces destalinizacji życia publicznego i samej sztuki, nie przypadkiem nazywany metaforycznie Odwilżą. Ważne, aby dostrzec przy tym, iż istota tej przemiany nie zawierała się w akcie nagłej konwersji.

Rozbrat artystów z socrealizmem nie wyrażał się jedynie poprzez gest odrzucenia obowiązujących dotąd schematów i ideologiczno-estetycznych matryc, lecz oznaczał o wiele więcej: świadomy zwrot w stronę tego, co prywatne, osobiste i intymne. Właśnie owo zbiorowe odkrycie indywidualnej osobności, a wraz z nią sfery prywatnej i intymnej człowieka (łącznie z perspektywą metafizyczną) przyniosło w efekcie metamorfozę i rozkwit sztuki polskiej przypadający na okres przed i po roku 1956.

To wtedy właśnie narodził się polski Kammerspiel - występujący z podobną wyrazistością w różnych dziedzinach fenomen rodzimej kultury i sztuki tamtego czasu. To wówczas twórcy skupili swą uwagę na odkrywaniu zaniedbanych dotąd i przemilczanych, intymnych pokładów ludzkiej osobowości. Miron Białoszewski w błysku genialnego poetyckiego skojarzenia potrzebował zaledwie dwu słów, aby rzecz określić, i nazwał ów wyróżnik i zarazem klucz do jego twórczości „wywodem jestemu”. „Wywód jestemu” okazał się jednak czymś więcej: specialité de la maison nie tylko samego poety, lecz również szerszego grona innych wybitnych reprezentantów sztuki polskiej Odwilży i Października. 
Zadajmy sobie w tym miejscu przewrotne pytanie: czy prywatność była zjawiskiem odrzuconym i całkowicie nieobecnym w sztuce socrealistycznej? Otóż, nie była i nie sposób obronić takiego twierdzenia, jeśli zna się - choćby tylko w miarę nieźle - dokonania polskiego socrealizmu w rozmaitych dziedzinach twórczości. Owszem, prywatność (której pod żadnym pozorem nie wolno mylić z intymnością) pojawiała się od czasu do czasu w poezji socrealistycznej, w prozie, sztukach plastycznych, dramacie czy filmie. Była to jednak całkiem inna prywatność. Rzec można, prywatność z obowiązkowym znakiem ujemnym: sfera ludzkiego życia traktowana z zasady podejrzliwie jako coś zbędnego, nagannego i - co najgorsze - asystemowego.

Sztuka na usługach ideologii służyła złej sprawie, a społeczny koszt tego sprzeniewierzenia miał się okazać wysoki. Mozolne wykuwanie „człowieka na miarę nowych czasów” - będącego w istocie monstrualną kukłą i makietową abstrakcją wyobrażaną w brązie, marmurze, na kartach książek, w obrazach malarskich i na ekranie - paradoksalnie, unieważniało głębszy sens ludzkiego życia, zamieniając je w coś zbędnego i nieistotnego. Doktryna stalinowska na swoich transparentach manifestacyjnie wypisywała hasło „człowiek najwyższym celem”, ale jednostką (czytaj, pojedynczym człowiekiem) pogardzała. Zwykłe życie, a zwłaszcza szara codzienna egzystencja milionów niewolników była istnieniem nie na miarę ideału: ledwie tolerowanym, spychanym przez propagandę w niebyt i przemilczanym. Pamiętamy - „jednostka niczym”. Czego się obawiali ci, którzy na co dzień siali straszliwy terror? Każdego i w każdej chwili można było przecież aresztować, skazać, uwięzić, poniżyć, zamęczyć, pozbawić życia. Skąd więc brał się ten paradoksalny strach władzy przed pojedynczym człowiekiem?

Rzecz w tym, że prywatność w czasach stalinizmu to groźna siła. Groźna, bo pozostająca poza wszelkim wpływem i kontrolą władzy. Ukryta w cieniu, milcząca prywatność nie do końca zniewolonego człowieka, który mimo wszystko usiłuje zachować osobistą niezależność i obronić dla siebie, choćby najmniejszą nawet, ale jakże cenną przestrzeń własnej wolności. Z tego właśnie powodu, dla nadzorców systemu i ludzi mu uległych, prywatność była sferą w cieniu podejrzenia.

Widmem totalitaryzmu pozostaje człowiek spoza szeregu: nieodgadniony, nie do końca rozpoznany, niekoniecznie spiskujący, ale niepogodzony z szarą rzeczywistością outsider. Ktoś skryty, kto po cichu usiłuje się przeciwstawiać, buntuje się i szuka dla siebie innej drogi.

W świecie totalnie zniewolonym, a przez to nieludzkim, taka prywatna przestrzeń nie ma prawa istnieć. A jednak istnieje - zepchnięta na margines, ukryta, zakonspirowana $\mathrm{w}$ wierszu nie do druku, dzienniku pisarza, w obrazie, który nie ujrzy światła na żadnej wystawie, rzeźbie schowanej na zapleczu pracowni, w nieprawomyślnym filmie, który nie trafi do kin. lecz decyzją cenzora zostanie od- 
łożony na półkę. To przestrzeń dramatu tępionej jednostki: ocalona, wyrwana nieludzkiemu światu, na przekór dyktatowi ideologii, cenzurze i sztuce oficjalnej.

W szczególnie wysokim stopniu dążenie do wyrażenia prywatności (resp. integralnego charakteru własnego ja) dotyczy grupy naszych znakomitych artystów okresu powojennego: od Borowskiego, Iwaszkiewicza, Miłosza, Lutosławskiego, Dąbrowskiej, Dygata, Słonimskiego, Jaremy, Kantora i Różewicza, poprzez Linkego, Nałkowską, Herberta, Munka, Hasa, Leca, Filipowicza, Bursę, Wróblewskiego, Białoszewskiego i Mikulskiego, na Krasińskim, Lebensteinie, Tyrmandzie, Brzozowskim, Konwickim, Mrożku, Nowosielskim, Komedzie i Szapocznikow poprzestając, ale bynajmniej nie kończąc. Zestawienie tych indywidualności pozwala dostrzec coś jeszcze. Przekonuje mianowicie, iż kurs na prywatność bynajmniej nie miał w tym przypadku związku z różnicami pokoleniowymi.

Trzeba też zauważyć, że prywatność jako temat i motyw artystyczny dochodziła wielokrotnie do głosu już w sztuce polskiej lat 1945-1949. Jej istotny ślad zawierało w sobie wiele znakomitych wierszy (przykładowo zbiór poetycki Niepokój Różewicza, Traktat moralny i Toast Miłosza), utworów dramatycznych (Dwa teatry Szaniawskiego, Teatrzyk „Zielona gess” Gałczyńskiego) opowiadań, obrazów malarskich, nawet filmów (by przywołać tylko pierwotną wersję Robinsona warszawskiego Jerzego Zarzyckiego oraz debiutancką Harmonię i Moje miasto młodego Hasa). Mimo frontalnej z nią rozprawy, prywatność występowała również - wprawdzie sporadycznie, ale jednak - w sztuce podporządkowanej doktrynie socrealistycznej. Co ciekawsze, nie zawsze potępiana i egzorcyzmowana, a zatem - w wersji niebezpiecznej dla obywateli kraju budującego socjalizm.

Odróżnijmy w tym miejscu autentyczną nieocenzurowaną prywatność, jaką na różne sposoby próbuje wyrazić wolny artysta tamtych czasów we własnym dziele, od jej udawanej pseudoartystycznej namiastki. Tę pierwszą jako przejaw osobistej wolności, niesubordynacji i buntu jednostki tępiła natychmiast czujna cenzura. Stąd pokątny charakter tego rodzaju twórczości, będącej w gruncie rzeczy zaciekle niszczoną przez ustrój „prywatną inicjatywą”. Poza nią funkcjonował jednak przecież inny akceptowany przez władze - jeśli nawet nie oficjalnie popierany, to w każdym razie mile widziany - wariant prywatności w postaci „człowieka pracy” po pracy, jak w opowiadaniu Iwaszkiewicza Dziewczyna i gołębie albo komedii obyczajowej Fethkego Irena do domu. Niekoniecznie inżyniera dusz i wielkiego rewolucjonisty, raczej szeregowego budowniczego „nowego jutra”, dla którego w odgórnie zaprogramowanym totalnym porządku codziennej egzystencji obok pracy liczą się także: życie rodzinne, domowe zacisze, wycieczka za miasto, rozrywka w wesołym miasteczku, potańcówka, impreza sportowa, urlop w ośrodku wczasowym i oferowany przez państwo ludowe odpoczynek na świeżym powietrzu. 
Tą właśnie drogą dokonywało się w sztuce i w życiu codziennym „zagospodarowanie” przemyślnie zsocjalizowanej prywatności jako sfery aprobowanej przez ustrój. Zamiast żyć dla siebie, bohater socrealistyczny oddychał, śnił i wypoczywał dla innych. Jak daleko sięgała ideologiczna czujność cenzora - owa sztucznie stworzona marionetka, wymodelowana z plasteliny bądź papier maché atrapa człowieczeństwa topornie wbudowana w Orwellowską rzeczywistość, nie miała prawa urzeczywistniać sobą niczego innego ponad cele wyznaczone przez najlepszy z ustrojów. Jej pożądaną inkarnację stanowił zarówno sekretarz partii, młodzieżowy aktywista, nauczycielka, zetempowiec, mistrz sportu czy funkcjonariusz aparatu bezpieczeństwa, jak i przodownik pracy.

Szersze panoramiczne spojrzenie na sztukę i kulturę polską czasu Odwilży i Października pozwala dostrzec istotną prawidłowość: zmianom polegającym na rezygnacji z odgórnie wytyczonego kursu i odrzuceniu powszechnie dotąd obowiązującej doktryny sztuki odpowiada generalny zwrot ku kameralności i prywatności. Sięgnijmy po przykłady. Leopold Tyrmand jako autor Dziennika 1954 stawia konsekwentnie na „życie towarzyskie i uczuciowe”. Aleksander Jackiewicz, publikując w roku 1956 tom swoich felietonów i szkiców o filmie, nadaje mu znamienny, domowy rzec by można, tytuł Latarnia czarnoksięska. W kioskach tysiące czytelników kupują, często spod lady, popularne tygodniki „Świat” i „Przekrój” czytane w domowym zaciszu, przy kawie i do poduszki. Zwłaszcza „Przekrój” umiejętnie unika oficjalnego tonu i wszelkiej koturnowości, traktując czytelnika w swoisty dla siebie sposób jako konesera i bywalca - kogoś zorientowanego w aktualnych trendach kultury i zainteresowanego, jeśli nie wręcz zafascynowanego, sztuką nowoczesną: Dos Passosem, Beckettem, Picassem, Dalim, Cocteau, Camusem, Saganką, Dürrenmattem, Frischem, Witkacym, Schulzem, Gombrowiczem, Ellą Fitzgerald, Ellingtonem itp.

Co innego też nadaje ówcześnie ton polskiemu życiu kulturalnemu. Jego oficjalny główny nurt, z jednej strony, i twórczość, powiedzielibyśmy dzisiaj, offowa, z drugiej - zamieniają się miejscami. Zjawiska dotąd peryferyjne budzą coraz większe zainteresowanie, nie tylko wśród elit. Na spotkanie ze sztuką chodzi się nie do Sali Kongresowej, udekorowanej auli czy świetlicy, lecz do prywatnych mieszkań, pracowni, atelier na poddaszu, klubów studenckich i piwnic. Modern jazz grają muzycy amatorzy w rodzaju Komedy, Miliana i Ptaszyna[ ${ }^{2}$ ]. I to jak grają.

Pojawia się nowy typ adresata sztuki, nowy styl jej indywidualnego odbioru i nowy rodzaj wrażliwości. Już nie wiersz skandowany przez megafon, lecz intymna liryka osobistego zwierzenia spod znaku 
Obrotów rzeczy (poezja łyżki durszlakowej, kołdry, pieca i szafy trzydrzwiowej) albo nasycona ironią, finezyjna refleksja poetycka $\mathrm{z}$ tomu Struna światła. Nie monumentalny teatr, a teatrzyk. W modzie są: Piwnica pod Baranami, Od Nowa, Bim Bom, Eterek, Teatrzyk Piosenki i teatr poetycki w prywatnym mieszkaniu na Tarczyńskiej. Złote lata w budowaniu wartościowego kontaktu ze słuchaczami przeżywa Polskie Radio. Nie Andrzej Bogucki z Chórem Czejanda i nie pieśń masowa w stylu Nieodłączne siostry dwie, Na prawo most, na lewo most czy Budujemy nowy dom, a piosenka liryczna. Zwłaszcza ta o zabarwieniu intymnym, której ulubionymi głosami stają się: Sława Przybylska, Kalina Jędrusik i Ludmiła Jakubczyk, a hasłami wywoławczymi: Hotelik „Pod Różami”, „staruszek portier”, „pokój numer osiem”, „szeptem”, „dwie szklaneczki wina”, „piosenka o okularnikach”, i przekorny szlagwort z początku lat 60. - „a ja mam swój intymny, mały świat” w wykonaniu Igi Cembrzyńskiej.

Sztuka polska lat Odwilży i Października specjalizuje się w kreowaniu mikroklimatów. Artyści różnych dziedzin okazują się mistrzami w tworzeniu niepowtarzalnej atmosfery i intymnych nastrojów w poezji, prozie, filmie, teatrze, muzyce, piosence. Intymny refleks przenika też polskie malarstwo. Tadeusz Mikulski u progu Odwilży maluje Drewnianego ptaka, a w 1957 Ptaka uwięzionego, Jerzy Krawczyk Akty, Andrzej Wróblewski Matki, Kajetan Sosnowski cykl obrazów Pamiętnik liryczny, Zbigniew Pronaszko Starego człowieka, a Jan Lebenstein Stary Rembertów i Widok na Nowy Rembertów [3].

Każdy z wymienionych obrazów w niezmiernie kunsztowny sposób operuje sygnałami prywatności i intymności, umiejętnie dobranymi z palety malarskich środków wyrazu. Prace wspomnianych artystów wyróżnia zarówno akcent położony na to, co osobiste, jak i wspólny mianownik zainteresowania prywatnością. Aspekt osobisty łączy się w nich z indywidualnym przeżyciem i intymnym doświadczeniem. Jedno i drugie sprawia, że dzieła tych twórców - przy niewątpliwej odmienności indywidualnych stylów i uprawianych przez nich odmian malarstwa - wiele z sobą łączy.

Za rewelacyjny wariant opisywanej tu transformacji sztuki polskiej w czasach Odwilży i Października uważam, nie całkiem docenione przez historyków polskiego kina, trzy pierwsze filmy Jana Lenicy i Waleriana Borowczyka $z$ lat 1956-1958. W momencie ich powstania, uważano je za nieszkodliwe dziwactwo, oceniane z reguły w kategoriach debiutanckich próbek i ekscentrycznego awangardowego eksperymentu. Ich głębszy, bynajmniej niebłahy sens odsłania dopiero wpi-

[3] Obraz olejny Widok na Nowy Rembertów (1955) zasługuje na osobny komentarz. Jan Lebenstein namalował na nim posępny zimowy krajobraz stołecznego przedmieścia z kościołem w tle. Zważywszy na kult „nowego" panujący w stalinizmie, tytuł ma wymowę gorzko ironiczną. Malarz z premedytacją wyko- rzystał w nim dwuznaczność nazwy Nowy Rembertów (będącej częścią przedmiejskiej dzielnicy wschodniej Warszawy, gdzie zamieszkała po wojnie rodzina Lebensteinów), prezentując w swym obrazie widok tyleż ponury, co zastygły w czasie, ,zamrożony” i niezmienny, jakby nietknięty ustrojową przemianą. 
sanie w macierzysty kontekst dokonań artystycznych tamtego czasu. Stają się wtedy utworami tyleż na wskroś nowoczesnymi, co niezwykle nośnymi znaczeniowo jako emanacje idywidualnego „ja”, intymne w swym wyrazie wypowiedzi liryczno-dramatyczne kreowane w języku ruchomych obrazów.

Był sobie raz..., Nagrodzone uczucie i Dom okazują się dzisiaj kapitalnym filmowym aneksem między innymi do wierszy Mirona Białoszewskiego z tomów Obroty rzeczy i Mylne wzruszenia. W zestawieniu z tą poezją, można je wręcz potraktować jako animowany załącznik do niej, który - podobnie jak ona - zawiera w sobie wszystkie najważniejsze wyróżniki nurtujące ówczesną twórczość, z jej kameralnym wydźwiękiem, liryzmem, poczuciem humoru, zadumą nad życiem, przekorną obroną ludzkiego „ja”, zainteresowaniem prywatnością i życiem intymnym człowieka. Pierwsze animacje duetu Lenica-Borowczyk zaskakują do dzisiaj oryginalnością formy i dojrzałością przesłania. Uważam te znakomite filmy za niezwykle charakterystyczne w swym wyrazie, modelowe wręcz dokonania sztuki polskiej lat 1956-1958, stawiając je w rzędzie najwybitniejszych osiągnięć artystycznych tamtego okresu.

Wymowną cechą polskiej rzeźby z kolei (Szapocznikow, Ślesińska, Zbrożyna i inni) staje się całkowicie zrywający z monumentalizmem format figury ludzkiej, jej sylwetka, głowa, tors czy popiersie ukazane w skali 1:1. Nie olbrzymi monument, ani górująca nad przechodniem potężna figura wtopiona w fasady gmachów MDM czy bryłę Pałacu Kultury, lecz zwykłego formatu człowiek - ukształtowany na miarę krawca, nie Fidiasza. Jego naturalna cielesność - bywa że ułomna i niedoskonała - zostaje wydobyta i wyeksponowana po to, by wrażenie pomnika ustąpiło wrażeniu rzeźby z natury (natury nie poddanej retuszowi, takiej jaka ona jest). Oglądając ją, czujemy obecność żywego modela, którego niepowtarzalne cechy znalazły się w centrum zainteresowania samego artysty i adresata jego dzieła.

Analogiczne zjawisko obserwujemy w polskim filmie tamtego czasu, gdzie wielki plan montażowy, wykoncypowany niegdyś przez Eisensteina[4] i radziecką awangardę filmową lat 20. (ros. 'krupnyj płan'), ustępuje miejsca zbliżeniom służącym (dosłownie) maksymalnemu zbliżeniu widza do bohatera. Widać to między innymi w Człowieku na torze, Kanale, Trzech kobietach, Pętli i Eroice. Zasadnicza zmiana funkcji semantycznej wielkiego planu, o której tu mowa, apogeum swego nowego wyrazu osiągnęła w przepięknej scenie miłosnej w Popiele i diamencie Wajdy, w której Jerzy Wójcik sfilmował chwile miłosnego zbliżenia Maćka i Krystyny w pokoju hotelowym. W filmach socrealistycznych - od Pancernika Potiomkina i Czapajewa

[4] S. Eisenstein, Dickens, Griffith i my, przeł. I. Piotrowska, w: Wybór pism, wybór, wstęp i redakcja Reginy Dreyer, Warszawa 1959; S. Eisenstein, $W$ zbliżeniu, przeł. M. Kumorek, w: Wybór pism, wybór, wstęp i redakcja Reginy Dreyer, Warszawa 1959. 
do Młodej gwardii, Młodości Chopina i Żotnierza zwycięstwa - wielki plan służył heroizacji bohaterów. W filmach polskiej szkoły filmowej ten sam wielki plan, wprost przeciwnie, służy ich uczłowieczeniu[5].

SZTUKA WYMAGAJAZCA
Odrzucając krępujące wymogi narzucone przez doktrynę socrealistyczną i uwalniając się od jej presji, artyści natrafili wkrótce na inny rodzaj ograniczeń. Rzecz w tym, iż znaczenia szczególnie cenne dla sztuki polskiej okresu Odwilży i Października, nie mogły zostać odpowiednio zaakcentowane i wyrażone wprost. Dlatego wiele z nich należy czytać w sposób metaforyczno-symboliczny, pojawiają się bowiem w postaci kunsztownie przetworzonej i przemyślnie zaszyfrowanej. Właściwa im ekspresja (malarska, liryczna, graficzna, taneczna, teatralna, filmowa, etc.) opiera się na stosowaniu subtelnych i wieloznacznych niedomówień.

Język sztuki Odwilży i Października, paradoksalnie, na tej aluzyjności nie stracił, lecz zyskał w tym sensie, że środki artystycznego wyrazu osiągnęły w niej niezwykle wysoki stopień sublimacji i subtelnej złożoności. Nie było przecież tak, że cenzura w 1956 nagle zniknęła. Jej chwilowe zelżenie miało charakter przejściowy. Artyści nadal musieli się liczyć z różnego rodzaju cenzorskimi ingerencjami. Aby tego uniknąć, wykształcili na własne potrzeby niezwykle skuteczne, ale też bardzo wymagające formy komunikacji, która wysoko zawiesza poprzeczkę adresatowi.

Nie chodzi tu o samą grę w chowanego z cenzurą, lecz o coś więcej. W cenie są: finezja, rafinada, przewrotność i bogactwo skojarzeń. Wirtualny adresat sztuki tamtego okresu jest kimś dobrze zorientowanym, obytym we własnej kulturze, nie stroniącym od trudności i wieloznacznego sensu utworu. To ktoś, kto umie odczytać parodystyczny komizm i aluzyjny charakter językowych niuansów w opowiadaniach Mrożka z tomu Słoń (1957), uśmiechnie się ze zrozumieniem, słuchając piosenek Kabaretu Starszych Panów (początki 1958), nie nudzi się nawet przez chwilę podczas Spacerku staromiejskiego Munka (1958), zdolny jest wyłowić najbardziej złożone sensy Ballady od rymu Białoszewskiego (1959). Umie też znaleźć coś dla siebie w awangardowych przedstawieniach teatru Tadeusza Kantora Cricot2 (m.in. Mątwa Witkacego, 1956), Operze za trzy grosze Konrada Swinarskiego (1958) czy we wczesnych spektaklach Teatru 13 Rzędów Jerzego Grotowskiego z lat 1958-1959.

Jeśli przyjrzeć się temu zjawisku z szerszej perspektywy, widać, że umiejętność niedosłownego odbioru dzieła sztuki stanowi pierwszorzędnie ważny wymóg kultury artystycznej tamtego okresu. Wy-
[5] Podobna refleksja interpretacyjna dotyczy innego wynalazku operatorskiego charakterystycznego dla poetyki polskiego kina lat 5o., jakim stało się często w nim stosowane ujęcie zza pleców bohatera. Opisany sposób ustawienia kamery i budowania narracji uruchamia podwójną niejako perspektywę widzenia, umożliwiając widzowi bieżącą obserwację rzeczywistości z punktu widzenia postaci, podkreślmy: naocznie obecnej w kadrze. Chwyt ten można by określić mianem narracji uczestniczącej, pozwala ona bowiem maksymalnie zbliżyć do siebie i zestroić w jedno: osobę widza z osobą bohatera filmu. 
magające dzieła powołały do istnienia model samodzielnie myślącego adresata. Nieprzypadkowo, podziwu godny poziom funkcjonalności estetycznej osiągnęły wówczas: groteska, purenonsens, absurd, liryzm, czarny humor i ironia. Wymienione kategorie estetyczne należą do kluczowych w sztuce Odwilży i Października. Powszechność ich stosowania, a także dynamika ekspresji połączona z motywem prywatności i intymności sprawiły, iż wykształcił się wkrótce specyficzny, wyrafinowany - obecny w różnych dziedzinach sztuki - styl będący tyleż finezyjnym, co przewrotnym kodem porozumienia między artystą a publicznością. Styl ten perfekcyjnie opanował między innymi młody Roman Polański, czego rewelacyjnym przykładem są Dwaj ludzie z szafa (1958).

Do najważniejszych dokonań polskiego filmu w drugiej połowie lat 50. ściśle związanych z kursem na intymność zaliczam ponadto: Człowieka na torze Munka, Zimowy zmierzch Lenartowicza i Pętlę Hasa (1957), Popiót i diament Wajdy (1958) i Ostatni dzień lata Konwickiego (1958) oraz Nikt nie woła Kutza (1960). W dokumencie na plan pierwszy wysuwają się: Dom starych kobiet (1957) Jana Łomnickiego, Pamiątka $z$ Kalwarii Jerzego Hoffmana i Edwarda Skórzewskiego (1958) oraz Z Powiśla... (1958) i Muzykanci (1960) Kazimierza Karabasza - wszystkie ze zdjęciami Stanisława Niedbalskiego. Ale za utwór modelowy - arcydzieło rodzimego Kammerspielu końca lat 50., będące swoistą kwintesencją dokonań artystycznych tego nurtu poza kinem - uważam Kartotekę Tadeusza Różewicza (1960).

Odkrywanie intymności i prywatności bohaterów przybierało w ówczesnej sztuce rozmaite formy. Raz okazywało się opisem obyczajów, kiedy indziej tzw. „małą historią” lub rejestracją strumienia osobistych przeżyć, a jeszcze innym razem zaszyfrowaną biografią pokolenia (Niewinni czarodzieje, 1960). Zawsze jednak wiązało się ono z osobistym doznaniem i jednostkowym doświadczeniem człowieka angażując nie tylko „ja” artysty, lecz również domagając się w odbiorze empatii ze strony adresata jego twórczości.

Cztery ściany domowego zacisza, knajpa, kawiarnia, akademik, klub studencki, pensjonat wczasowy, hotelik na prowincji... Czas, który ucieka, choć zdaje się nie istnieć dla ludzi niezmiennie tkwiących na bocznym torze zastygłej w drodze donikąd rzeczywistości. Biedna, pełna goryczy, dokuczliwa codzienność, a w niej bohaterowie mimo wszystko próbujący żyć po swojemu. Twórczość artystyczna lat Odwilży i Października nie jest sztuką buntu. Nieraz zarzucano jej wycofanie, defensywny charakter i eskapizm. Nie była też (albowiem być wtedy nie mogła) działaniem otwarcie politycznym. I dobrze. Znamionuje ją co innego: filozofia trwania i przetrwania. Prywatność i intymność, jakim sztuka ta hołdowała, stanowiły dla niej swoisty azyl i residuum - miejsce, w którym można odnaleźć i wyrazić siebie. Uchwycony na różne sposoby strumień ludzkich przeżyć i komunikat artystyczny będący zapisem osobiste-

OBRONA

BEZBRONNYCH 
go doświadczenia okazują się dla nas po latach najcenniejszą jej wartością.

Wprawdzie Arystoteles w dziele Polityka twierdził, że homo politicus pozostaje niezbywalną rolą człowieka jako istoty stworzonej do życia w państwie, jednak sztuka drugiej połowy lat pięćdziesiątych w Polsce nie była ani działaniem stricte politycznym, ani tym bardziej szańcem buntowników. Jeśli już, to raczej z trudem wywalczoną strefą dla azylantów. Ludziom zamieszkującym tę strefę nikt niczego nie obiecywał, ale na co dzień zapewniała ona przynajmniej względny spokój egzystencji. No i, rzecz niezwykle ważna dla artysty - prawo do robienia czegoś, czego się chce. Jeśli relacje społeczne i działania tego typu uznać za formę działalności politycznej, artysta tamtego okresu - tyleż bezbronny, co z uporem walczący o minimum własnej niezależności - nolens volens, istotnie stawał się człowiekiem politycznym.

Nie było zatem otwarcie demonstrowanego buntu, ale sztuka czasów Odwilży i Października '56 stała się w pewnej mierze formą niezgody i stawiania osobistego oporu. Nie sposób twierdzić, iż są to dzieła tworzone przez dysydentów. Artyści tamtej doby czują się jako ludzie i obywatele bezbronni, mają też świadomość ograniczonej roli uprawianej przez siebie sztuki. Zwłaszcza na przełomie lat 50. i 6o., w fazie rozprawy ideologicznej ze zdobyczami Października, widać wyraźnie, iż chodziło o przetrwanie. Poetów, prozaików, dramaturgów, scenarzystów, reżyserów, malarzy, grafików, aktorów, muzyków tamtego okresu łączy wspólna im wszystkim postawa artystyczna. Nie istniała przy tym żadna, przyjęta a priori, grupowa deklaracja, ani zbiorowy manifest. Postawę tę można odczytać z ich prac, jeśli potraktować je domyślnie jako - wyposażony we wspólny mianownik - zbiorowy hipertekst.

Można oczywiście dyskutować, czy na przykład ludziom pióra (Białoszewski, Herbert, Mrożek) bądź choreografom (Tomaszewski, Drzewiecki, Gruca) wolno było wtedy nieco więcej niż filmowcom (w rodzaju Munka, Hasa i Wajdy) czy ludziom teatru (Kantorowi, Swinarskiemu, Zamkow), czy odwrotnie. Nie należy jednak rozdrabniać i kawałkować refleksji nad sztuką Odwilży i Października, dzieląc ją wedle granic poszczególnych dziedzin sztuki. Niniejsze „studium przedmiotu" próbowało pokazać, iż należące do niej dzieła stanowią łącznie multidyscyplinarny poliptyk: wielodziedzinową jedność. Jedność uchwytną w wielości. Sztuka polska tych lat nie jest całością monolityczną i jednogłosową, lecz formacją o charakterze polifonicznym, w granicach której współistnieją z sobą różne poetyki i rozmaite dążenia: nie tylko współbieżne i nawzajem komplementarne, lecz niekiedy także wewnętrznie sprzeczne.

W artykule Polska szkoła filmowa jako formacja artystyczna [6] eksponując bogactwo i wewnętrzną złożoność nurtu „szkoły polskiej”

[6] M. Hendrykowski, Polska szkoła filmowa jako for-

macja artystyczna, „Kwartalnik Filmowy” 1997, nr 17. 
- dążyłem do ukazania swoistości owego fenomenu jako szerszego ideowo-artystycznego uniwersum. Nic nie stoi na przeszkodzie, aby kategorię „formacji ideowo-artystycznej” zastosować jeszcze szerzej: również w odniesieniu do całej sztuki tamtego okresu. Wbrew obiegowym opiniom, nie była to twórczość eskapistyczna ani tym bardziej ulegle podporządkowana polityce. Kompromisy i ustępstwa, jakie z konieczności zawierała, należały tyleż do nieuchronnych, co gorzkich.

Intymność i sfera prywatna człowieka jako temat sztuki polskiej tamtego okresu nie stanowiły jej wąskiego marginesu ani ślepego zaułka. Wprost przeciwnie, okazały się drogą twórczo kontynuowaną w sztuce następnej dekady. Widać to wyraźnie między innymi w: Nożu w wodzie Polańskiego, Świadectwie urodzenia i Głosie z tamtego świata Stanisława Różewicza, Tangu Mrożka czy serii znakomitych dramatów Tadeusza Różewicza z lat 6o. Ten sam kierunek poszukiwań daje o sobie znać również w: Jak być kochana i Szyfrach Hasa, Rysopisie, Walkowerze i Barierze Skolimowskiego, Zaduszkach i Salcie Konwickiego, Kordianie, Księciu Niezłomnym i Apocalypsis cum figuris Grotowskiego, Nie-Boskiej Komedii w inscenizacji Swinarskiego, a także w znakomitych filmach telewizyjnych, jakie wyszły spod ręki Różewicza, Majewskiego, Zanussiego, Żebrowskiego i in.

Dokonania artystyczne zyskują historyczną ważność dzięki ich kontynuacjom. Specyficzne wartości wytworzone przez sztukę czasu Odwilży i Października zdołały mimo wszystko przetrwać. Dzisiaj widać, że postawa artystów tworzących w tamtym okresie znalazła swój ciąg dalszy także później w: Kabarecie Starszych Panów Przybory i Wasowskiego, wierszach poetów nowej fali, obrazach malarskich grupy Wprost, grafikach Gaja, Gielniaka, Mroza i Rózgi, spektaklach teatrów studenckich dekady lat 70., karykaturach prasowych Czeczota, Mleczki i Krauzego, filmach Kieślowskiego, Marczewskiego, Holland i in. spod znaku kina moralnego niepokoju.

Rangę sztuki polskiej okresu Odwilży i Października wyznacza jej prekursorski względem sztuki europejskiej program artystyczny ogarniający swym zasięgiem rozmaite pola twórczości: kino, literaturę, sztuki plastyczne, teatr, kabaret, taniec etc. Zwykło się przy tym mówić - dość jednostronnie i bardzo niesprawiedliwie - o bezkrytycznym zapatrzeniu w kulturę Zachodu, powszechnej nią fascynacji i przemożnym wpływie egzystencjalizmu na polskich artystów, zamiast widzieć w tym niezwykle cenną inspirację, która - twórczo zaadaptowana i przetworzona - zaowocowała serią zdumiewająco świeżych i odkrywczych dokonań. Osiągnięć, które zapisały na swym koncie wszystkie dziedziny sztuki i do których warto powracać po latach. 